\title{
Landscape of Possibility
}

\section{Community Filmmaking in Indonesia as a Relational Process}

\author{
Rosalia Namsai Engchuan | ORCID: 0000-0003-1224-6211 \\ Max Planck Institute and Friedrich-Alexander University, \\ Berlin, Germany \\ rosalianamsai@gmail.com
}

\begin{abstract}
This essay is driven by the question of how Candra, the writer and director of Dewi pulang (2017), is able to sustain his cinematic practice, despite the controversial nature of his films. Considering the notion of landscape of possibility, this essay traces processes that precede and go beyond the production of a particular film, but which are nevertheless constitutive of its becoming. These entanglements are explored through concrete stories in dialogical engagement with film practitioners in Indonesia. Adding these to the conversation of what constitutes a film conceptually and analytically, the desired gesture of this essay is less a representation or documentation of Candra's practice or Indonesian film communities but rather a provocation to approaches in film studies that operate on binary assumptions of landscape as an external backdrop (of text and context, film and maker, state and film production). I will argue that the evolution of film communities in Indonesia challenges commonly held assumptions about the role of the state in 'independent' film, and the linear 'assembling logic' from 'grassroots' to 'mainstream'.
\end{abstract}

\section{Keywords}

community film - constitutive technicity - collective organizing - film censorship 
Not so many films talk the way I talk to my friends.

I am planning to make a web series about abortion.

About being independent but asking for money from parents and about the hook-up culture.

About the things we don't normally talk about.

These are our stories.

It shows Jakarta youth.

This is how we are. ${ }^{1}$

Candra is a filmmaker who pushes for topics that are important and genuine but unconventional, because they expose uncomfortable truths about young adult life in contemporary Indonesia. He makes fictional films which are grounded in reflections on the experiences that he and his friends have had living in Jakarta. He told me that 'Dewi is $75 \%$ me' (2020). Candra's cinematic practice pushes for the elasticity of taboo topics to be brought into the public sphere. His films are easily accessible on the Viddsee platform and are screened in many community-organized spaces. ${ }^{2}$ This essay is driven by the question of how Candra is able to sustain his cinematic practice, despite the controversial nature of his films. I am tracing this question using a relational-processual analysis that maps out the micro-processes that are often black-boxed ${ }^{3}$ as 'context of production' (Harvey 2007).

In this essay, I think through this question with the notion of landscape of possibility. I am drawing on Stiegler (1998), who in Technics and time offers a conceptual language for the relationship between humans and technics-the

1 These are excerpts from conversations with Candra that I have partly translated and edited. Some of them took place in person, others via WhatsApp or in the course of our discussions alongside the writing of this article.

2 Viddsee is a Singapore-based online short-film platform with more than 4500 films. Dewi pulang can be found here: https://www.viddsee.com/video/dewi-goes-home/de5og?locale= en.

3 The term is used by Bruno Latour to talk about 'a process that makes the joint production of actors and artifacts entirely opaque' (1999:183) making it 'difficult to measure, with any precision, the mediating role of techniques' (1999:183). This interest in 'the mediating role of techniques' (1999:183) is what drives me in my study of film. 
nature of which is constitutive, not instrumental. ${ }^{4}$ Thinking with his philosophy of technology in the context of my study, I conceive a film text as a complex network of numerous constituents (money, laws, technologies, values, ideologies). ${ }^{5} \mathrm{~A}$ film text comes into being through the relations among all these elements (see also Lam 2015). The landscape of possibility insinuates a shift in analytical focus towards all that precedes and goes beyond a particular film text, but which is constitutive of its genesis. It conceives of the context as operational. The notion of landscape of possibility allows us to think about the notion of 'possibility' in the context of film production in a non-binary way: not as something given and external but as something that is constantly remade and reconfigured.

Methodologically, I am embarking on this endeavour together with other practitioners. My practice of thinking 'with' rather than 'about' is inspired by Trinh T. Minh-ha's notion of speaking nearby and is also reflected in the contemplations of Tim Ingold (see Chen 1992; Ingold 2019). Both call for going beyond tangential and extractive encounters with research collaborators. The argument developed here derives from 13 months of ethnographic fieldwork in Indonesia during 2018 and 2019, mainly on the island of Java, and from ongoing conversations during further trips to Indonesia, on WhatsApp, as well as the more formalized conversations leading towards this special issue. The following thoughts are a response to numerous encounters and conversations, in particular with:

- Candra, the director and writer of Dewi pulang, whom I first met after a film screening at the Goethe-Institut in Jakarta and whom I have already introduced at the beginning of this essay.

- Tito Imanda, a scholar of Indonesian cinema, and also a filmmaker and anthropologist. Before doing a PhD in Anthropology at Goldsmiths College, University of London, he was the head of the School of Media and Communication at BINUS International University, involved in 'activism for better political conditions surrounding the Indonesian cinema: ${ }^{6}$ When I met him, he was the head of education on the Badan Perfilman Indonesia (вPI, Indonesian Film Board), and he was fundamental in facilitating my research with this government body.

4 See also Hui 2016.

5 See also Gallope 2020; Simondon 2017.

6 https://international.binus.ac.id/media-communication/people/imanda/ (accessed o8-o32021). 


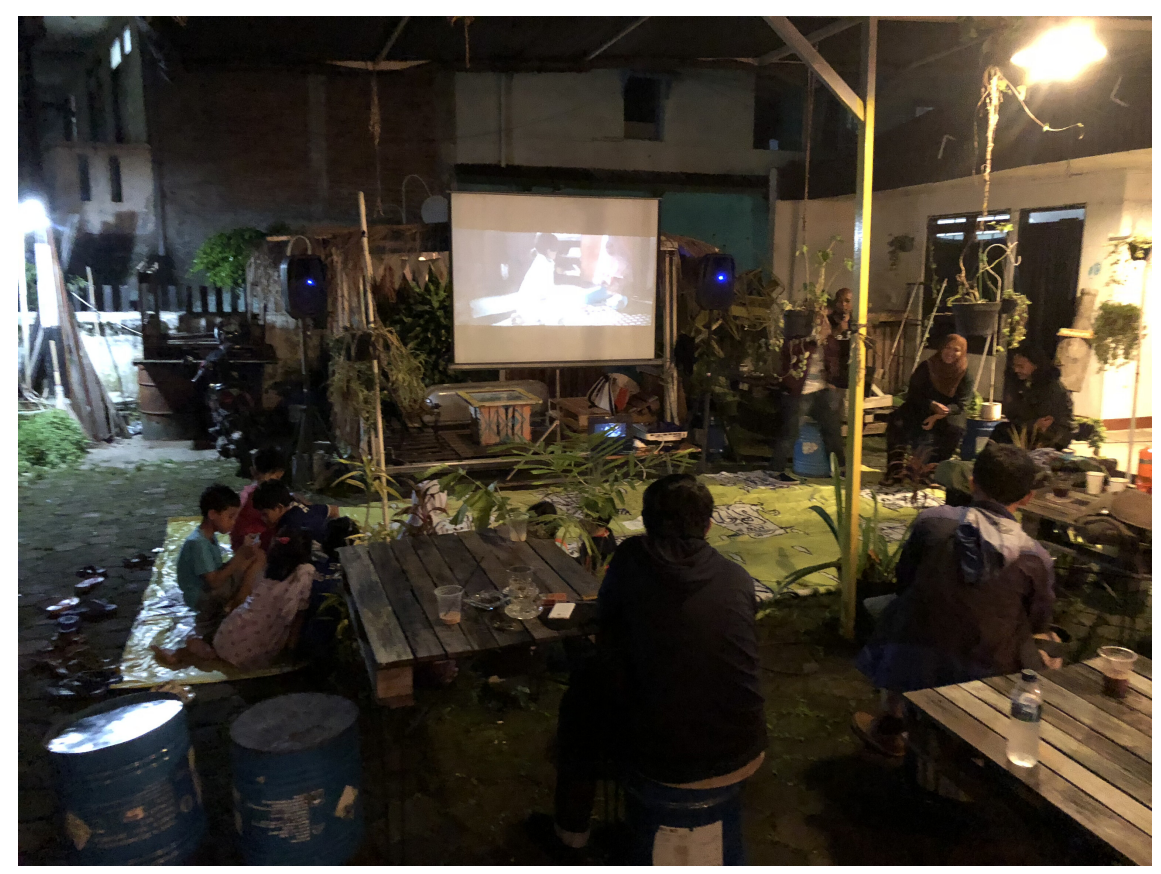

FIGURE 1 Community film screening in Bandung, Indonesia, 2018

- Lulu Ratna, who is sometimes referred to as the mother of Indonesian film communities. She has been part of the post-reformation independent film scene since the early beginnings. She was involved in the establishment of Konfiden, 'a non-profit organization focusing on fostering socialization and public's appreciation of short films in Indonesia' (Mediarta 2007:308) and in the organization of the first film festivals after reformation. With her organization Boemboe and as a lecturer at Universitas Multimedia Nusantara (UMN), she is still active in the komunitas film environment.

- Deden M. Sahid, whom I met at a local komunitas film screening in Bandung (depicted in Figure 1). He organizes filmmaking workshops and screenings, facilitating the sharing of knowledge and resources. During our conversations we talked mostly about the question of motivation to help friends 'for free' and the sustainability of film communities. He stressed again and again that formalization is an important part of this trajectory from the nonformalized system 'where no one takes responsibility'?

7 Personal communication with Deden Sahid in 2018. 
Candra's practice is part of the wider komunitas film phenomenon, an assemblage of film communities all over Indonesia whose activities pivot around the making, screening, and discussing of (mostly) short films. ${ }^{8}$ The term komunitas film can refer to one particular community, mostly attached to a university campus, as well as to these film communities collectively. Most komunitas film emerged in the more liberal environment that developed following Indonesia's political reformation in 1998, along with the deregulation of the film industry that had been heavily centralized during the preceding New Order regime. The dawn of digital filmmaking technologies was a key enabler in the expansion of film communities, as it made the medium of film accessible to wider ranges of society. In this essay, I will argue that in addition to technology and political conditions it is also a particular mindset of collectivity (gotong royong) that acts as a driver for cinematic practice.

I am speaking of cinematic practice rather than filmmaking, because komunitas film do not only make films but also create screening spaces. There are regular, local film screenings on university campuses, at cafés, or at other improvisational cinemas and on a yearly or bi-yearly basis, depending on funding and manpower, there are film festivals in different cities that take place over several days. At these festivals, film communities from different places meet, present their works, engage in dialogues surrounding the issues depicted in the films, and also reflect on the current state and future of komunitas film (how to get funding, how to approach screening spaces, how to facilitate knowledge transfer).

Thinking of the manifold activities described before on a conceptual level, komunitas film is not an entity but a relational configuration, a fluid assemblage of relational processes that territorialize and intersect in particular spaces (cinematic and social). ${ }^{9}$ From an ecosystem perspective, a film screening, for

8 For an overview of the events and actors, refer to Barker (this issue) and Jayasrana 2007; Ratna 2007; Prakosa 2005; and Van Heeren 2012.

9 The notion of territorialization is most commonly used in the context of the work of Deleuze and Guattari (1980), but other scholars have operationalized the notion in other contexts, mostly in relation to the nation. For a good overview please refer to Brighenti 2010. In my analysis of komunitas film, I am thinking with the notion of territorialization to conceptualize 'the interplay between physical space and the organization of relations and functions that comes along with it, within and throughout a territory' (Brighenti 2010:59). This allows me to think about the social and cinematic spaces that are created within the komunitas film ecosystem: the film screenings, the festivals, the film productions, as well as the films themselves as 'an act or practice rather than an object or physical space' (Brighenti 2010:53). 


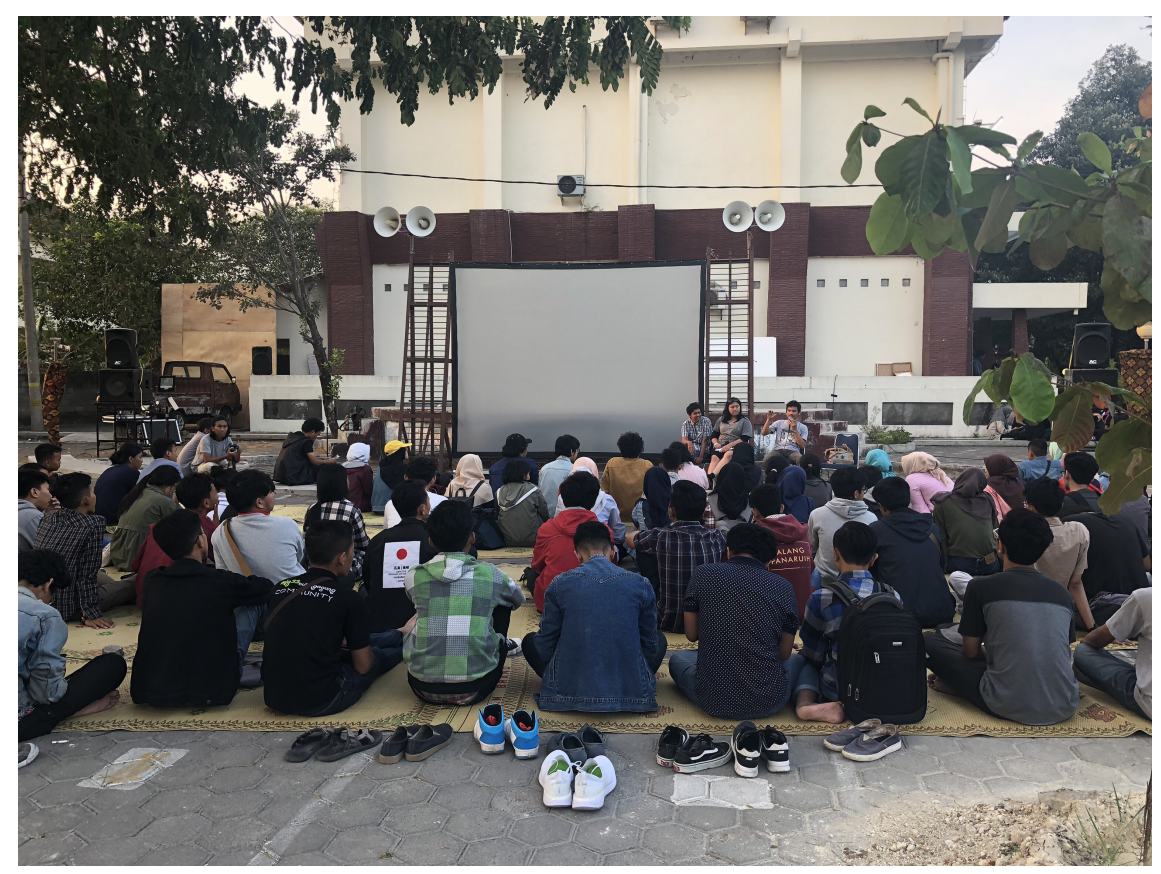

FIGURE 2 Discussion on gender and sexual politics after a film screening at Is Y Yogyakarta, Indonesia, 2018

example, might be the beginning of the film as an 'object', an 'artifact that gains multiple resonances', and the beginning of its acting as a 'text', as 'a site and space for critical analysis, inquiry, and engagement' (Harvey 2007:263). ${ }^{10}$ It can also be the beginning of a friendship that turns into a film, or someone will be taking notes on a certain camera angle and this inspiration will become constitutive of their new film text. The logic of genesis is one of radical relatedness. In order to analytically untangle these complex entanglements, I attempt to trace some of these relations as well as the grammar of relation-making.

10 This focus on the process is thought of as a complementary analysis that works best in conjunction with, not as a replacement of, a more textual analysis. For a comprehensive analysis of the modes of translation of Dewi pulang, refer to Fox (this issue); see Meyer (this issue) for a reflection on 'presence and absence' in Dewi pulang. 


\section{On the Grammar of Relation-Making}

Through our conversations about his life and career, I learned that Candra was a film critic and blogger before he became a filmmaker:

So, I started to write a blog in 2006. I was sixteen back then.

I wanted to meet all the filmmakers and I thought that if my writing was

good enough maybe they would want to meet me.

That was my idea.

I wrote about how badly I wanted to be a filmmaker and that I reviewed films.

Then Tito contacted me, and a few months later I moved to Jakarta.

Tito rented a place for me, a very small studio with no windows.

It was fun.

He arranged my scholarship.

When I say it now it sounds like a very surreal experience.

Tito was developing a film programme as the head of the School of Media and Communication at BINUS International University when he contacted Candra. Candra and Tito's connection in this example demonstrates the central importance of people-to-people connections and networks of relationships. Candra's nascent trajectory as a filmmaker further illustrates how the political and technological context concretely shape the landscape of possibility for him to become a filmmaker. Only the Internet and access to digital films enabled Candra to watch and write about them and eventually to be found by Tito. This climate of digital filmmaking technology and more freedom of expression enabled relations to form, as they allowed actors to connect. It was the time when film communities started to mushroom all over Indonesia.

But the potential to connect does not automatically translate into action. An analytical gaze that conceives of technology as a relation is interested in the nature of the relation between the technology and the human: the grammar of relation-making. This notion attends to the question of how is this potential activated? I asked Candra how he finances his cinematic practice:

I never finance my own films.

The short films that I made usually got funding.

Or the one that didn't get funding was made via gotong royong with my friends. But those films were designed to be shot with minimal crew, talent, etc. Ngabuburit and Desire and my web series Ruang casting were made with gotong royong.

I also help friends with their productions. 
Candra's use of the term gotong royong is significant here, because it hints at a mode of production that does not follow the logic of capitalist exchange. Gotong royong is a Javanese term for a form of collaboration that is not primarily based on immediate material exchange, and it alludes to a particular way of doing things together. Gotong royong in this context refers to helping a friend make a film with no financial compensation. When the notion was first introduced to me in another conversation with Deden, he described it as follows: 'Making a film is teamwork. Jangan dibayar, enjoy aja (do not pay, just enjoy) - spend time together.' Deden alludes to some of the core characterizations of gotong royong: the collaborative character (teamwork) and the nonmaterial/monetary character of the transaction (jangan dibayar) as well as the process orientation (spend time together). It is important to acknowledge that not only is the evolution of komunitas film enabled by the political climate after the reformation of 1998 and technological advancements, it also thrives on a particular form of collaborative mentality and practice. ${ }^{11}$

\section{An Assembling Logic of Their Own}

Many filmmakers start out in collaboration with friends. But Candra pointed to the limits:

But I don't want to be dependent on it.

I mean, if I have a good friend but they only work for money or they can't work pro bono, I'm fine with that too.

I think having friends who can help you do anything, especially make a film, is a privilege.

Candra's reluctance to depend solely on gotong royong reflects the fact that we live in a world where there is no outside to capitalism. There is a desire and need to make cinematic practice sustainable for film practitioners, to find some kind of future and space in the world with filmmaking. And this requires the entrance of funding into networks of film production.

11 His casting of gotong royong in a positive light (enjoy aja) is notable, because it is in stark contrast to the way the term is described in existing scholarly accounts that refer to its use under former Indonesian regimes as an instrument of governance to extract 'labour which is mobilized on the basis of political status or subordination' (Bowen 1986:548). I will examine the appropriation of this loaded term by contemporary cultural practitioners at length in my forthcoming dissertation and cannot discuss this at length in this essay. 
In assessing the current state of filmmaking, many people I spoke to in Indonesia shared the following diagnosis: the local film ecosystem is an 'underdeveloped local film industry, not yet an entity'. And, as Tito remarks, 'each industry [...] need[s] to find their own assembling logic' (Imanda 2014). Candra became a filmmaker at a particular moment in time, when the film ecosystem was transitioning from its early and 'wild' grassroots character towards something else. Many of these processes precede and go beyond Candra's career, but they are constitutive of his practice. The founding of institutes like the BINUs film school and Akademi Film Yogyakarta (Jogja Film Academy) is part of a larger movement of institutionalization and professionalization in a sphere in which, in the past, community-organized film workshops provided training. Additionally, filmmaking was put on the agenda of cultural production by the Indonesian government. There were several processes that preceded this move. In 2009 a new film law (Law of the Republic of Indonesia Number 33 of 2009 on Film) was introduced, with stricter censorship regulations for local productions as well as quotas for the screening of foreign films. Tito told me that 'the film law stated that the government, central and regional, must support film.' ${ }^{2}$ Despite early worries about the harmful effects of the law, it became a productive actor for local short film production and circulation.

Under Jokowi's presidency (2014-), the Pusat Pengembangan Perfilman (Pusbangfilm, Indonesian Film Development Board) was created to 'become a coordinator in the formulation of policies that favour Indonesian cinema in order to create a healthy and competitive ecosystem. ${ }^{13}$ Dewi pulang was financed by the Pusbangfilm under a programme to facilitate the production of short films. The Badan Perfilman Indonesia (BPI, Indonesian Film Board) is another embodiment of the 2009 film law, 'to increase community participation in film (Article 68). ${ }^{14}$ The film communities invested a lot of hope in this body, as reflected in the following statement by Lulu Ratna: 'Indonesia needs an institution that can lobby the government, that understands the legal issues, that is in a position of authority, and this is what we hope the BPI will be. 15

I joined in with some of the activities of the 2017-2020 board of the BPI in 2018. One day we went to Bakoel Koffie in Cikini to meet the founders of Viddsee, who signed a Memorandum of Understanding for the promotion of Indonesian short film. This initiative included the organization of the Viddsee jury awards in Jakarta in 2018, in which Candra's film was included. There is a

\footnotetext{
12 Personal communication with Tito Imanda in 2020.

13 https://pusbangfilm.kemdikbud.go.id/page/read/7 (accessed o8-o3-2021).

14 http://bpi.or.id/tentang.html (accessed o8-o3-2021).

15 Personal communication with Ratna in 2014.
} 
connection between the meeting in Cikini and Candra's film now being available on this online platform. The way in which elements within the network come together is not a coincidence but rather the result of hard work by people who are both part of the state in their function as BPI members, and at the same time part of the komunitas film ecosystem. Alex Sihar, for example, the head of policy advocacy of the BPI has a past in the film communities: he is the founder of Yayasan Konfiden (Konfiden Foundation) and organized 'the first Indonesian Independent Film and Video Festival in 1999' (Mediarta 2007:308), which triggered the mushrooming of film production and communities all over Indonesia.

The idea of independent short-film production as something outside of the state crumbles once one takes on a processual perspective and investigates the larger ecosystem of film production. In Candra's cinematic practice, the state is not something the film encounters as an entity; it breathes through its very being. It is part of the funding structure of Dewi pulang and cannot be thought of independently of Tito, the BPI, the MoU with Viddsee, and numerous other relations that make up the landscape of possibility for Candra. This leads me to expand Stiegler's argument on the constitutive nature of humans and technology to the sphere of the state, which is also constitutive of the cinematic ecosystem and the film.

\section{5}

\section{Porous Landscape}

What does it mean, however, that the state is to be thought of as constitutive of the landscape of possibility for filmmaking? When talking about instances of film censorship, filmmakers, scholars, and critics alike often frame the state in binary opposition to the film and filmmaker-as an outside actor that steps in through censorship at a time when the film is already finished. Likewise, the 'independent' in independent film, even though heavily debated, often implies independence from the state or commercial distribution channels (controlled by the state through film censorship). This is even more the case in Indonesia, a country that has lived through decades of violent state oppression. To gain a more in-depth understanding of the complex mechanics of censorship already at work during the film production process, I asked Candra if he sees a pattern regarding which stories are made with friends, and which get funding:

[For state-funded films] I can't make an explicit sex scene or sex jokes or anything LGBT-themed. The one that I get to make by myself is so freeing in terms of creative choices. 
However, it was possible to produce Dewi pulang, a film that contained a taboo representation of a teenage girl smoking, even though it was supported by Kementerian Pendidikan dan Kebudayaan (Indonesian Ministry of Education and Culture):

There was a fight about the smoking scene.

Because, apparently, when they screened it in front of the important

people, they were shocked.

I fought for it because I felt it was important.

I feel like that element is part of her character.

And also one of the main things that highlights how Dewi has changed.

Well, Dewi has become a smoker because now, she has smoker friends.

When she still lived in the village, she was pretty vanilla.

They said that they would censor it.

But I heard they didn't do it.

What we are looking at is dialogical genesis, where Candra, the Film Development Board, censorship policies, and cultural norms with regard to young girls smoking are always already intimately entangled. The reality of film censorship here was not a binary clash between entities - the film and the censor-but a process of circumstantial negotiation and co-creation.

\section{Conclusion: We Are the Landscape, We Make Possibilities}

The funding structures facilitating Candra's cinematic practice now are a mix that does not rely exclusively on support from friends. He has made other short films with the Komisi Pemberantasan Korupsi (K PK, Corruption Eradication Commission) Film Festival and the Dinas Pariwisata (Indonesian Tourism Agency). In his position at Provoke magazine, he negotiated and created an opportunity to make his web series:

I talked to the editor and I told him he lacked video content.

I said 'You have to compete now with all the other platforms.

I will do it very cheap but not extravaganza.'

We made a trial episode.

The owner liked it and allowed me to make it.

I had a budget of 18 million (roughly $€ 1100$ ) for six episodes. 
Candra continuously adapts - there is no template or path he follows to make and screen films. It is at its core an improvisational practice. ${ }^{16}$ He works with what presents itself and creates opportunities, despite the challenges of late capitalism and the rise of conservative norms in Indonesia. Landscape of possibility is also a comment on agency. The filmmaker here is thought of as an active part of the landscape that shapes his/her practice and not as a passive victim to outside conditions.

What can be characterized as improvisation on the level of individual practice, on a meta-level of scale and temporality presents us with a larger picture of the 'assembling logic' (Imanda 2014) of film communities in Indonesia. The stories pivoting around Dewi pulang; the early generation of film community organizers becoming part of the BPI and therefore the state apparatus; the founding of formalized film schools as an impetus from within the film communities as well as Candra's creative trajectory: all suggest that film communities in Indonesia indeed do have their very own 'assembling logic'. It is one that does not merely follow a developmental trajectory from loosely organized grassroots formations towards a 'mainstream' form (from 'modern' to 'developed') but is instead a more complex process of becoming, which is entangled in webs of both personal relationships and institutional contexts.

\section{References}

Bowen, John R. (1986). 'On the political construction of tradition: Gotong royong in Indonesia', The Journal of Asian Studies 45 (May 1986):545. https://doi.org/10.2307/ 2056530 (accessed 8 March 2021).

Brighenti, Andrea Mubi (2010). 'On territorology: Towards a general science of territory', Theory, Culture \& Society (5 March). https://doi.org/10.1177/o263276409350357. (accessed 8 March 2021).

Chen, Nancy N. (1992). '"Speaking nearby": A conversation with Trinh T. Minh-Ha', Visual Anthropology Review 8-1 (March 1992):82-91. https://doi.org/10.1525/var.1992 .8.1.82. (8 March 2021).

Deleuze, Gilles and Félix Guattari (1980). Mille plateaux. Paris: Éditions de minuit.

Gallope, Michael (2020). Technicity, consciousness, and musical objects. Music and consciousness. Oxford: Oxford University Press.

Harvey, Sophia Siddique (2007). 'Nomadic trajectories: Mapping short film production

16 The notion of 'improvisation' is a characterization of Indonesian film practice that was also put forward by Paramaditha 2014. 
in Singapore'. Inter-Asia Cultural Studies 8, no. 2: 262-76. https://doi.org/10.108o/ 14649370701238730 .

Heeren, Katinka van (2012). Contemporary Indonesian film: Spirits of reform and ghosts from the past. Leiden, Boston: Brill. [VKI 277.]

Hui, Yuk (2016). The question concerning technology in China: An essay in cosmotechnics. Falmouth: Urbanomic.

Imanda, Tito. (2014) 'Sekolah film di Indonesia: Sebuah refleksi (Film schools in Indonesia: A reflection)', cinemapoetica.com. Translated from https://cinemapoetica.com/ sekolah-film-di-indonesia-sebuah-refleksi/2014.

Ingold, Tim (2019). 'Art and anthropology for a sustainable world', Journal of the Royal Anthropological Institute 25-4 (December):659-75. https://doi.org/10.1111/1467-9655 .13125. (accessed8 March 2021).

Jayasrana, Dimas. (2007). 'Notes from the underground: Film activism in small town Java', Asian Cinema (Fall/Winter):112-8.

Lam, Anita (2015). Making crime television: Producing entertaining representations of crime for television broadcast. First edition. London: Routledge.

Latour, Bruno and Centre de Sociologie de L' Innovation Bruno Latour (1999). Pandora's hope: Essays on the reality of science studies. Cambridge, MA: Harvard University Press.

Mediarta, Agus. (2007). 'Konfiden and the promotion of Indonesian short films', InterAsia Cultural Studies 8-2 (1 June 2007):308-9. https://doi.org/10.108o/1464937070123 8821. (accessed 8 March 2021).

Paramaditha, Intan (2014). The wild child's desire. Cinema, sexual politics, and the experimental nation in post-authoritarian Indonesia. New York: New York University.

Prakosa, Gotot (2005). Film pendek independen dalam penilaian: Sebuah catatan dari berbagai festival 'film pendek dan film alternatif' di Indonesia. First edition. Jakarta: Komite Film Dewan Kesenian dan Yayasan Seni Visual Indonesia. https://trove.nla .gov.au/version/13500299. (accessed 8 March 2021).

Ratna, Lulu (2007). 'Indonesian short films after Reformasi 1998', Inter-Asia Cultural Studies 8-2:304-7.

Simondon, Gilbert (2017). On the mode of existence of technical objects. Minneapolis: Univocal Publishing.

Stiegler, Bernard (1998). Technics and time. Vol. 1, The fault of Epimetheus, translated by Richard Beardsworth and George Collins. First edition. Stanford, CA: Stanford University Press. [3 vols.] 